\title{
Implementation of Environmental Issues in Teaching the Subject of Technical Education at Primary Schools
}

\author{
https://doi.org/10.3991/ijep.v10i4.13077 \\ Ivana Tureková ( $\left.{ }^{凶}\right)$, Jana Bilčíková \\ Constantine the Philosopher University in Nitra, Nitra, Slovakia \\ iturekova@ukf.sk \\ Alexander Bilčík \\ DTI University, Dubnica nad Váhom, Slovakia \\ Iveta Marková \\ University of Žilina, Žilina, Slovakia
}

\begin{abstract}
Nowadays, environmental issues belong to frequently discussed topics. Our article focuses on the implementation of environmental issues in teaching the subject of Technical education at primary schools in the Slovak Republic. Our research sample consisted of 123 students, graduates of primary schools in Trnava, Trenčín and Bratislava regions after they started to study at secondary vocational schools. We wanted to find out more information about their experience related to working with tools, instruments and machines, to developing their creativity, designing and manufacturing of their hand-made products. Our main questions dealt with environmental issues and their acquisition in the subject of Technical education. Up to $55.5 \%$ of respondents stated that they did not learn, or they did not remember the area of environmental issues within the given subject. $7.8 \%$ of respondents remembered mainly the topic of waste sorting out of all environmental issues discussed at the lessons of Technical education. In general, environmental aspects as cross-cutting topics of the educational process can be adequately demonstrated and implemented in the subject of Technical education. However, this implementation also requires a new conceptual approach to the teachers` education and the lifelong education of the whole society, as well
\end{abstract}

Keywords - Environmental education, cross-cutting topic, subject of Technical education

\section{Introduction}

Environmental education constitutes a core component of education for sustainable development [1]. Kansas [2] defined environmental education as a process directed at creating awareness and understanding about environmental issues that leads to responsible individual and group actions. Furthermore, the author describes that 
successful environmental education focuses on processes that promote critical thinking, problem-solving, and effective decision-making skills.

In designing the curriculum for environmental education scholars suggest different approaches. For example, researchers and policy makers have suggested that one of the most effective approaches to environmental education is one which is holistic in nature, meaning that it should be integrated through the whole school curriculum [3] - [7]. However, whatever approach is adopted, there will be need to consider the three interlinked dimensions of environmental education which comprise education about, in/from or through and for the environment, as pointed out by Palmer [3]. These components are interrelated and are essential components of environmental education planning at all levels. Fig. 1 below shows a model of curriculum design showing how the interrelated components of environmental education can be used in designing the curriculum for environmental education [9].

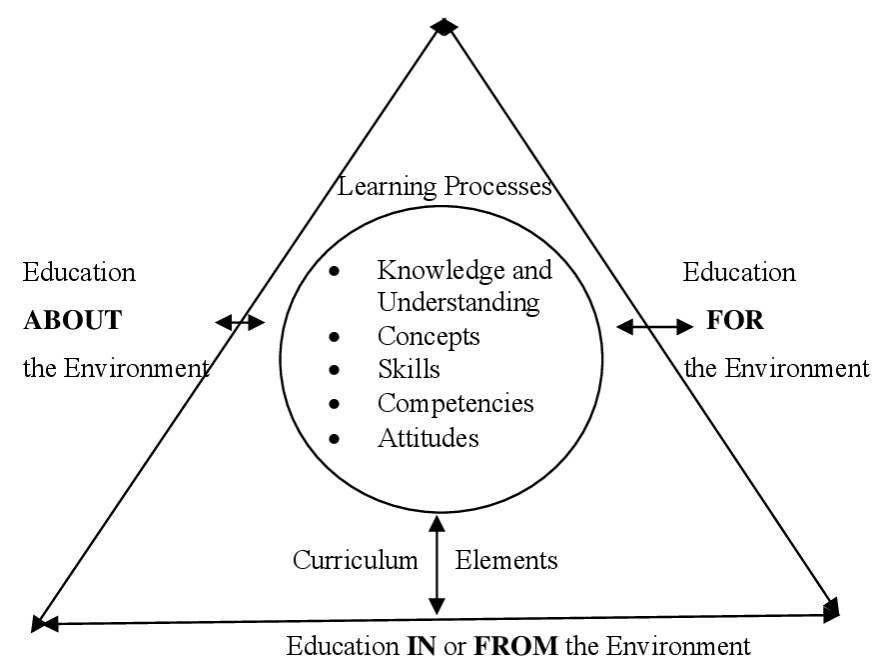

Fig. 1. Interrelated components in the planning of environmental education [8], [9].

The model developed by Palmer (1998) has been modified to include the aspect of competence. This model answers the question "what and why are they learning environmental education." The three components of environmental education, education about, in/from or through and for the environment. can be linked to the technical, practical and critical curriculum models [10], [11]. In the technical curriculum model, emphasis is on knowledge, skills and attitudes hence the tendency to support the aspect of education about the environment. The main curriculum concern in this model is subject content [12] - [14].

Environmental education should also be incorporated into technically oriented subjects at primary school. Through a deductive approach, we investigated how pupils remember the environmental aspects of teaching Techniques. 


\subsection{Environmental education in the Slovak Republic}

In Slovakia, the formal environmental education takes place in school facilities [15], and the State Educational Programme covers it from the pre-school education up to secondary vocational education [16]. In all levels of education, environmental issues represent cross-cutting topics belonging to corresponding educational areas. [17]. In general, school facilities at all educational levels, fulfil the contents of environmental education by numerous activities and projects. Facilities, which included environmental focus and aims in their school educational programmes and are involved in longterm projects, have a more comprehensive approach to these issues [18].

The Ministry of Education, Science, Research and Sport of the Slovak Republic coordinates the formal environmental education. At the same time, the Ministry of Environment of the Slovak Republic plays a significant role in the curricula creation with their recommendations [19]. The analytical part of the sector concept about the situation in environmental education in Slovakia provides the thematic SWOT analysis. We present its results for the Government department of Education in Table 1.

Based on the given analysis, there was defined the main aim of the sector concept for the environmental education: „To create a functioning integral system of the environmental education, instruction and formation in the Government Department of the Environment aimed at particular target groups, using innovative tools and maintaining the principles of sustainable development". Its offset should start in the year 2020. The website of the Slovak Environment Agency [20] presents particular activities for the following years.

The basis of the School Educational System of the Slovak Republic forms the twolevel model of education. [21]. The first level represents the obligatory State educational programme. The second level consists of school educational programmes which allow every school to reflect on specific regional or local conditions and requirements of pupils and their parents, offering them voluntary lessons and activities [22]. Crosscutting topics belong to the State educational programme:

- Personal and social development (education to marriage and parenthood)

- Environmental education

- Media education

- Multi-cultural education

- Health and life protection.

Schools can carry on the cross-cutting topic „Environmental education“ as part of the curricula of teaching subjects, or through separate lessons, seminars, lectures. They can also open a separate teaching subject within their voluntary lessons [23]. 
Table 1. SWOT analysis in the area of environmental education in Slovakia (chosen parts for the Government department of Education [15]

\begin{tabular}{|c|c|}
\hline $\begin{array}{c}\text { STRONG POINTS } \\
\end{array}$ & OPPORTUNITIES \\
\hline $\begin{array}{l}\text { - inclusion of environmental education in the } \\
\text { State Educational Programme in the form of } \\
\text { a cross-cutting topic } \\
\text { - several methodological materials about } \\
\text { environmental education for pedagogues } \\
\text { - manifold methodology of environmental edu- } \\
\text { cation }\end{array}$ & $\begin{array}{l}\text { - to develop study programmes aimed at } \\
\text { environmental education and to support them by } \\
\text { the State. } \\
\text { - to make environmental issues accessible for } \\
\text { pedagogues } \\
\text { - to create a system of preparation of future teachers } \\
\text { for the environmental education } \\
\text { - to cooperate systematically with various centres, } \\
\text { such as nursery centres, community and leisure } \\
\text { centres, clubs for pensioners. } \\
\text { - to develop and spread the cooperation at the } \\
\text { regional level through small workgroups, to use } \\
\text { examples of good practice } \\
\text { - to strengthen the cooperation at the international } \\
\text { level, e.g. exchange of methodology and } \\
\text { experience, and evaluation of environmental } \\
\text { programmes. } \\
\text { - to ensure publications and materials about } \\
\text { environmental education, to carry on programmes } \\
\text { and projects that is understandable also for } \\
\text { minorities and marginal groups }\end{array}$ \\
\hline WEAK POINTS & THREATS \\
\hline $\begin{array}{l}\text {-Environmental education as a cross-cutting } \\
\text { topic is carried on only in a formal way, there } \\
\text { is a non-systematic approach in the teaching } \\
\text { process (though several schools have made } \\
\text { significant progress in this area) } \\
\text {-Several educational activities in the } \\
\text { preparation of future pedagogues for } \\
\text { environmental education are only formal; } \\
\text { non-systematic education of teachers } \\
\text {-Non-systematic support of coordinators of } \\
\text { environmental education. There is } \\
\text { insufficient support by school management } \\
\text { and the lack of financial motivation at } \\
\text { schools } \\
\text {-There are missing unified and consistent } \\
\text { textbooks of environmental education for } \\
\text { primary and secondary schools }\end{array}$ & $\begin{array}{l}\text {-A competition of other topics at schools: } \\
\text { „competition“ of environmental education with } \\
\text { other cross-cutting topics } \\
\text {-A wrong understanding of the environmental } \\
\text { coordinators` role at schools: insufficient support } \\
\text { by school management and weak cooperation of } \\
\text { colleagues } \\
\text {-Cumbersome reactions of the system to current } \\
\text { educational challenges (several current issues are } \\
\text { missing in the cross-cutting topics of } \\
\text { environmental education } \\
\text {-Q non-existing social demand for a more effective } \\
\text { system of environmental education }\end{array}$ \\
\hline
\end{tabular}

\subsection{Environmental education within the subject of Technical Education}

There is an appropriation of one lesson a week dedicated to the subject of Technical education within the framework teaching plan for ISCED 2 in the educational area „People and the world of work“. This lesson has its defined standards in performance and contents. Topics consist of particular thematic units. At the same time, teachers have a chance to creatively modify the set teaching contents within the school educational programme according to particular school grades.

Thre cross-cutting topic of Environmental education can be applied within the subject of Technical education as well. The environmental education aims to achieve the following objectives to the end of ISCED education of pupils: 
- Pupils should know the basic rules of behaviour in nature, and they should respect all living creatures and their natural habitat;

- They should be able to recognise and evaluate changes in nature and their environment;

- Pupils should know options leading to protection and improvement of environment. They should participate in school activities focused on the protection and improvement of their broader environment of school omunicipality;

- Pupils should have information about the interventions of people in the environment. They should be able to evaluate their consequences in the local and global context;

- Pupils should be able to distinguish technologies and products which are environment-friendly;

- They should behave to natural resources in an environmentally friendly way;

- Pupils should participate actively in the elimination of pollution [24].

The educational standard consists of the subject characteristics and the primary teaching objectives, which form the performance standard. The standard of the contents defines the teaching contents. The concept of the educational standard (programme of pupils' activities) should create possibilities for cognitive activities of pupils, such as searching, seeking, observing, examining, discovering, manipulating with objects, experimenting, and constructing as an underlying assumption of developing their practical skills.

The educational standard of the teaching subject Technical education divides into two thematic fields: Technology and Household Economics. Both of these areas consist of several thematic units. In Table 2, we mention an example of the performance and contents standard for the thematic unit „People and technology“ for the fifth grade of primary schools.

Table 2. Requirements for the performance and contents standard of pupils at the end of the fifth grade of primary school (thematic field Technology, thematic unit People and Technology) [25]

\begin{tabular}{|l|l|}
\hline \multicolumn{1}{|c|}{ PERFORMANCE STANDARD } & \multicolumn{1}{|c|}{ CONTENTS STANDARD } \\
\hline $\begin{array}{l}\text { At the end of the fifth grade of primary school, } \\
\text { pupils are able: }\end{array}$ & - School rules, work rules in the technical workroom \\
- To follow the rules of Health and Safety Protection & - Technical - social - natural environment, \\
at Work, hygiene and behaviour, & Relationships between them, nature, negative influ- \\
- To explain the concept of technology in its nar- \\
rower and broader meaning, \\
- To give examples of positive and negative influ- \\
ence of technology on people, nature and society, \\
- To explain the need for a positive approach of peo- \\
ple to the creation of technology by specific exam- \\
ples, \\
- To write a project on a topic of nature protection
\end{tabular}

The cross-cutting topic of Environmental education requires thorough preparation and professional knowledge of environmental issues related to the standard of the contents of the given subject. 


\section{Methods}

In order to gather aggregate information about knowledge, opinions and attitudes to environmental issues taught at primary schools quickly, we chose a questionnaire survey (Novanská, 2017). We used a questionnaire with open questions that allowed us to examine the observed phenomena more thoroughly. At the same time, these questions reflect the real opinions and attitudes of respondents better. Processing of this type of questions is more demanding than other types of questionnaires. However, the obtained information and data are more valuable. The questionnaire consisted of six questions. Respondents answered to these questions anonymously, and they were not limited in time. The questions were the following ones:

1. Write the name of the primary school you attended.

2. Mention in which school years you had the subject of Technical education.

3. Write in which places you had the lessons of Technical education.

4. Name tools, instruments and machines you used at the lessons of Technical education.

5. Mention products you designed or manufactured at the lessons of Technical education.

6. Do you remember which environmental issues you learnt at the lessons of Technical education?

We chose the subject of Technical education to find out attitudes and opinions of pupils. This subject belongs to the basic general education of the population. At the lessons, pupils acquire manual skills in the school workroom. Moreover, this subject represents the basis of preparing for practical life and coping with real-life situations. From this point of view, Technical education is a subject that fully meets the requirements of modern education - connection of the given contents of education with real life. Therefore, it is suitable to implement the cross-cutting topic of Environmental education in its contents.

Our respondents were pupils who finished primary school and continued in their study at secondary vocational school of technical character in the Trnava region. We prepared and delivered the questionnaire to pupils at the beginning of September 2019. At primary school, all pupils had an obligatory subject of Technical education with the appropriation of one lesson a week. With the selection of our research sample, we wanted to obtain information about respondents' knowledge and attitudes to environmental issues which represent a cross-cutting topic, and belong to the performance and contents standards of Technical education. Our sample consisted of 123 respondents.

Our main aim was to find out which environmental issues (aspects) pupils remember from the lessons of Technical education. Subsequently, we wanted to examine which practical skills acquired in the given subject are useful for further education at secondary vocational school. 


\section{$3 \quad$ Results}

We intentionally formulated first question in such a way so that we could identify whether the primary school was in the regional capital, a district town, town, or a village (a municipality). On one side, the location of the school could evoke a closer relationship to the environment. On the other side, Trnava, as a regional capital, is an industrial city with environmental problems, as well. In winter 2019, experts measured higher concentrations of particles PM10. A crucial cause were the road traffic emissions, fuel heating and other local sources. Unfavourable scattering conditions also worsened the situation.



Fig. 2. Results in answers to the item no.1: ,Write the name of the primary school you attended".

From the obtained results, it is evident that most pupils attended primary schools in villages. The least number of pupils visited primary schools in towns that are not district towns.

The second item focused on acquiring information about the attendance of the subject of Technical education. We wanted to find out in which school years of the lower secondary education pupils had Technical education. The results are in Fig. 3. 


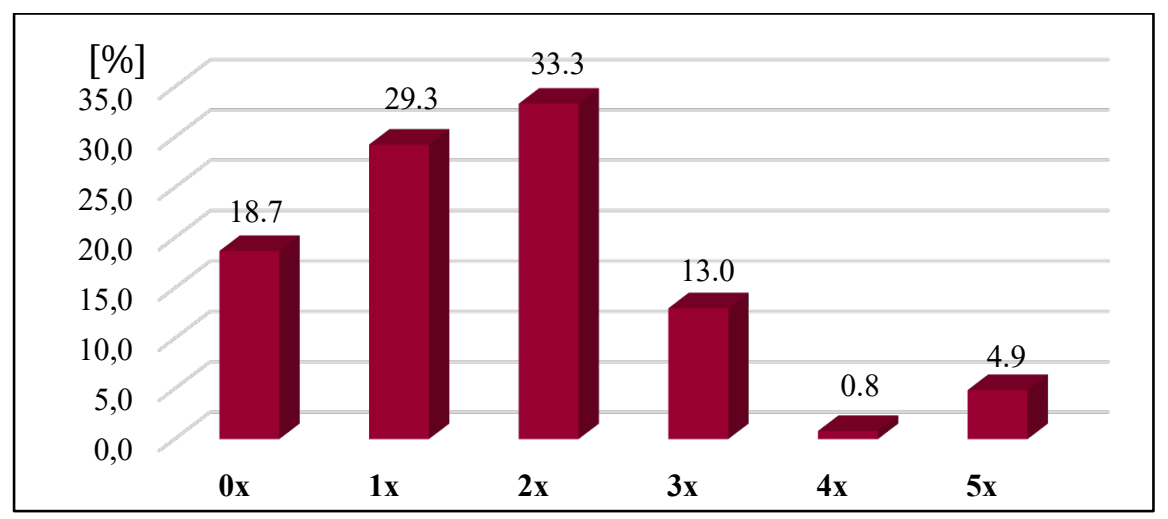

Fig. 3. Results in answers to the item no.2: "Mention in which school years you had the subject of Technical educatioN"

Up to $15 \%$ of pupils mentioned that, during the lower secondary education, they did not have the subject of Technical education at all. Only $5 \%$ of respondents answered this question correctly, saying that they had Technical education in every school year of the 2 nd grade of the primary school.

In the third item, pupils identified the places/objects where they had Technical education. We recorded the results in Fig. 4. This question focuses on their memories about the places and activities they did at the lessons of the given subject.

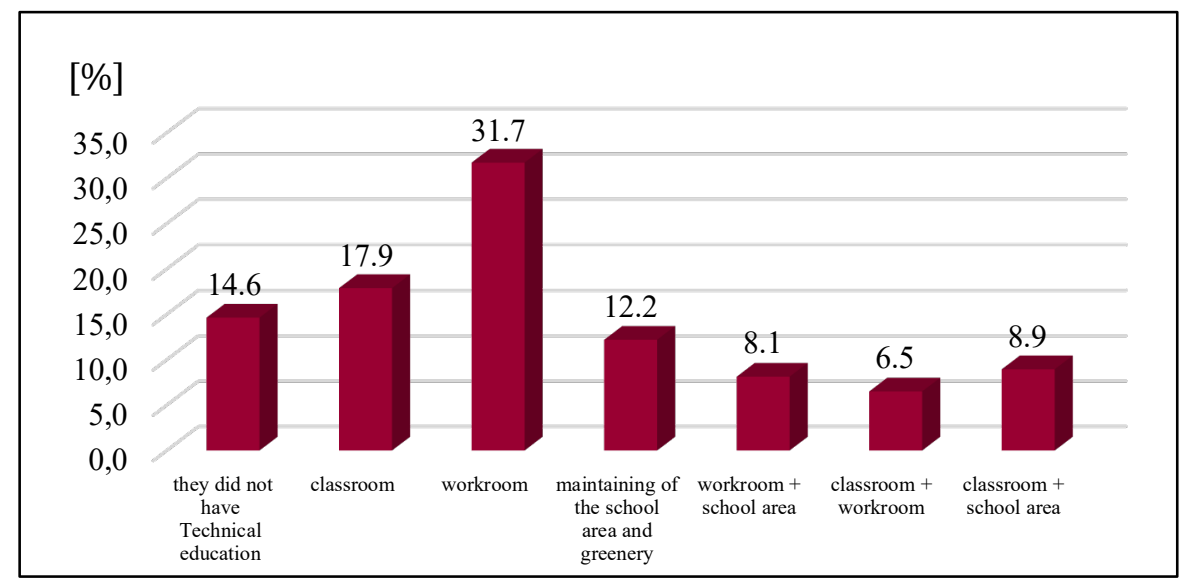

Fig. 4. Results in answers to the item no. 3: „Write in whic places you had the lessons of Technical education "

Since this was an open question, pupils could mention several objects and places connected with the lessons of Technical education. Up to $31.7 \%$ of pupils said they had Technical education in school workrooms. However, $14.6 \%$ of pupils stated that they did not have the given subject in the list of subjects at the primary school they attended. $17.9 \%$ of respondents said that they had Technical education in the regular classroom. Finally, $35.8 \%$ mentioned the combination of places: workroom, classroom 
and school area. They also remembered activities connected with the maintaining of the school area.

The objective of the fourth questionnaire item was to find out which tools and instruments pupils worked with at the lessons of Technical education (Fig. 5).

$33 \%$ of respondents mentioned that they did not use any tools nor instruments; 27.6 $\%$ of pupils used hand tools. $19.5 \%$ worked only with garden tools.

If the models of strategy of Technical education are applied and chosen correctly, and they implement working with tools and instruments at the lessons, they contribute to the development of the primary skills of pupils. Technical Education is an excellent example of a subject which motivates pupils to use their skills, imagery and creativity. In the following question (Fig. 6), we asked them which products they manufactured or designed at the lessons of Technical education.

In the fifth item, $52 \%$ of pupils mentioned they did not make any own product at the lessons of Technical education. Pupils also specified types of products they manufactured, such as products from wood, matchsticks, pendants, key pouches, pads, twisters, little trees, rattles, metal products and others.

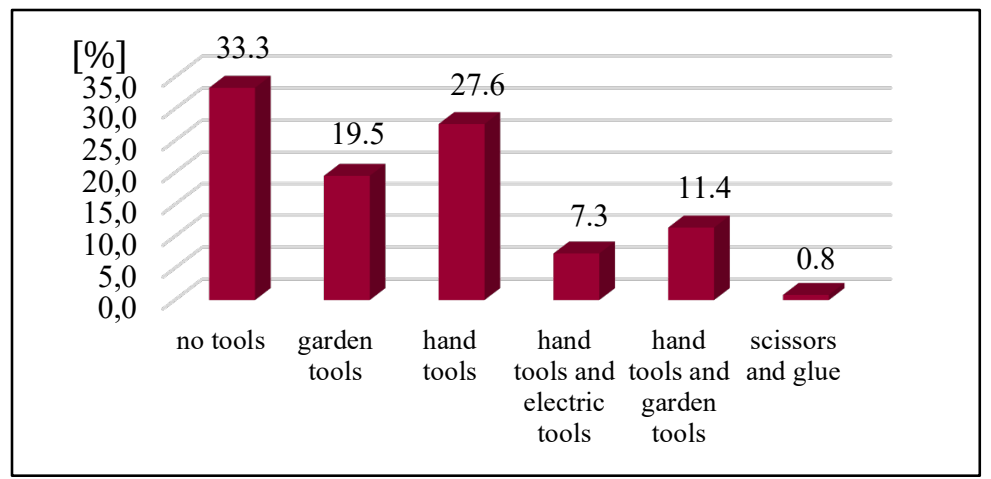

Fig. 5. Results in answers to the item no. 4: „,Mention tools, instruments and machines you used at the lessons of Technical education ".

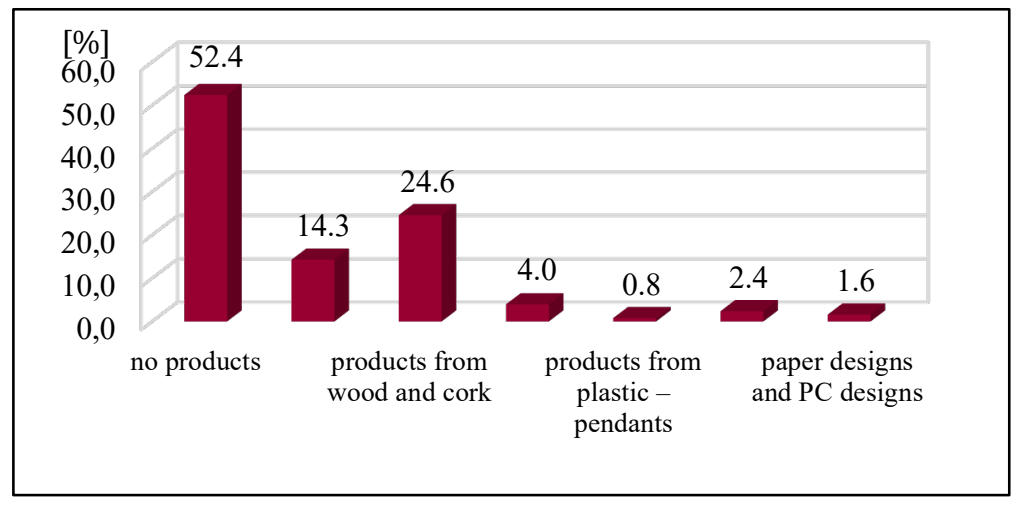

Fig. 6. Results in answers to the item no. 5: „Mention products you designed or manufactured at the lessons of Technical education ". 
Environmental education aims to develop pupils`environmental literacy and awareness about their environment so that they can protect, improve and love nature. For this reason, our last question focuses on the essential research topic. We wanted to find out if pupils remember which environmental issues they learnt at the lessons of Technical education. We recorded the results in Fig. 7.

$55.5 \%$ of respondents say that they did not learn about environmental issues at all. $7.8 \%$ of pupils do not remember whether they learnt about these issues or not. The most frequent environmental issue was the Waste issue (waste sorting and recycling), followed by the topics of renewable energy sources $(9.4 \%)$ and planting of trees.

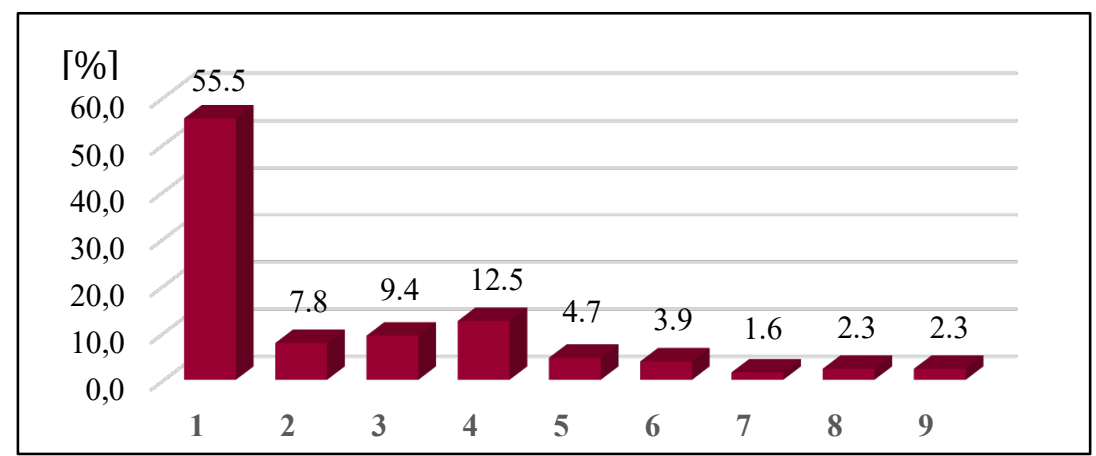

Fig. 7. Results in answers to the item no. 7: „Do you remember which environmental issues you learnt at the lessons of Technical education?"

1 - they did not learn, 2 - I do not know, I do not remember, 3 - using renewable energy sources, 4 - waste sorting, 5 - planting of trees, 6 - saving of water, electricity, 7 - heat insulation of building, 8 - waste recycling, 9 - they learnt but they did not specify the topics

\section{Discussion}

From the analysis of the obtained data, it is evident that preparation of pupils for technical thinking, as well as acquiring necessary working skills and habits, using suitable tools and instruments at primary schools in the observed region, is at a low level [28], [29]. At some schools, the maintenance of school areas replaces Technical education. As a consequence, pupils have a weak practical and technical preparation when they start studying at secondary vocational schools.

In general, environmental education of the youth does not meet the requirements of the current society; it does not provide the necessary skills and attitudes for adequately civilised citizens. Moreover, this form of environmental education does not achieve the standards of surrounding European countries. This insufficient approach has an impact on the fundamental environmental literacy and pro-environmental (or, rather antienvironmental) behaviour. 
One of the general goals in the new 2030 Sustainable Development Agenda of the sustainable development [30] is to bespeak, that all people will acquire knowledge and skills necessary for sustainable development by education about sustainable development lifestyle, human rights, gender equality, support of peace, global citizenship, and acceptance of cultural diversity.

The main aim of the cross-cutting topic of Environmental education is to contribute to the personal development of pupils in such a way that they will acquire the ability to understand, analyse and evaluate relationships between people and the environment. They will know the rules of life on the Earth, and they will understand all relations between the development of the human population and environment in different parts of the world. At the same time, they will be able to understand that there exists a relation between the global problems and their responsibility to the environment [17], [25], [31].

Despite several efforts, as well as official measures and activities, experts discuss the ineffectiveness of this system and its weak points, such as:

- Formalism

- Limited understanding of environmental education

- Absence of the system in the education of pedagogues

- Insufficient motivation for the coordinators of environmental education [32].

There is also inadequate support of non-governmental organisations and their activities by the State and competent institutions. However, these non-governmental organisations belong to significant subjects in the field of environmental education of children and youth in Slovakia.

Although 123 respondents do not form a representative sample, the study within the ESF project, called "The analysis of the system of environmental education in the Trencín region", obtained similar outputs. The main goal of this research was to find out how schools implement the cross-cutting topic of Environmental education [32]. They compared the current situation in the Trenčín region with the conditions in the Czech Republic. They identified the following weak points of our system:

- The lack of infrastructure and resources (e.g. financial, human, technical resources)

- The system of further education of teachers is non-systematic and non-conceptual

- The conceptual system of environmental education for administrative workers, the private sector and journalists, is missing, too

- The current institutional form of environmental education in the school system (the valid State educational programme defines Environmental education as a crosscutting topic) is non-conceptual and formal. Although pupils have sufficient environmental knowledge, the level of their skills and pro-environmental attitudes is deficient

- At all levels of education, there are missing the critical topics of environmental education, such as questions of personal responsibility, conscious modesty, self-sufficiency, adaptability, and mainly the question of personal and group civil involvement in environmental issues 
- Schools and other educational institutions do not adequately use the professional qualities of environmental non-governmental organisations and enthusiastic individuals

- There are significant differences between regions (also within regions) and between schools as well

- A modern concept and system is missing not only in the environmental education but also in the whole environmental politics of the State (all previous and current concepts are not valid, or they are not up-to-date)

- The departmental and sector responsibilities in the field of environmental education are not clearly defined.

According to the reactions of our respondents, we can assume that schools have problems with human resources when implementing environmental issues in the contents of the subject. Teachers are not involved enough in environmental activities. The activity and motivation of teachers and also pupils will probably improve after the generational change of pedagogical workers. Environmentally motivated teachers can motivate their pupils to be more active in this area. If these environmental issues are set in the State Educational Programme and also in the School Educational Programme, teachers should meet and fulfil these requirements. They cannot come up with excuses for the lack of financial resources or the lack of necessary information.

The improvement of the current situation will require much effort and further education of teachers. At the same time, teachers` cooperation with pupils` legal representatives will have to improve as well in order to prepare pupils for further study and productive life better. Pupils should acquire better technical knowledge and know the safety and environmental rules at their work.

\section{Conclusion}

Symptoms of global changes in recent years indicate that anthropogenic interventions in the environment are becoming limiting factors of our civilisation. These changes reflect in the reviewing of current strategical objectives of school and out-of-school education. The need for systematic and comprehensive environmental education is one of the main priorities that require thorough changes. The subject of Technical education has a cross-cutting topic of Environmental education in its contents in the second grade of primary schools. Our research, carried on with a sample of 123 respondents attending secondary vocational schools, confirmed a low level of pupils` knowledge of environmental issues. If we want to live according to the rules of sustainable development, it is necessary to educate teachers in the field of environmental education further. This step requires systematic support, relevant teaching aids, up-to-date publications, methodological and information materials. 


\section{Acknowledgment}

This article was supported by the Grant Agency of the Ministry of Education of the Slovak Republic: KEGA - project no. 014UKF-4/2020.

\section{$7 \quad$ References}

[1] Choi, J. I., \& Hannafin, M. (1995). Situated cognition and learning environments: Roles, structures, and implications for design. Educational technology research and develop-ment, 43(2), 53-69. https://doi.org/10.1007/BF02300472

[2] Kadji C. (2002) Evaluation of whole school environmental education, Kansas association for conservation and environmental education, Available at: www.kacee.org (Accessed October 2014].

[3] Palmer, J., \& Neal, P. (1994). The Handbook of Environmental Education. London: Routledge. 267 pp.

[4] Smyth, J. C. (2006). Environment and education: a view of changing scene. Environmental Education Research, 12 (3-4), 247 - 264. https://doi.org/10.1080/13504620600942642

[5] Tilbury, D. (1995). Environmental Education for Sustainability: defining the new focus of environmental education in the 1990s. Environmental Education Research, 1 (2), 195 - 212. https://doi.org/10.1080/1350462950010206

[6] UNESCO, (1977). First Intergovernmental Conference in Environmental Education. Final Report, Tbilisi, USSR. Paris: UNESCO.

[7] WCED (1987). Our Common Future, Oxford: University Press.

[8] Palmer, J. (1998). Environmental Education in the 21st Century: Theory, practice, Progress and Promise. London: Routledge.

[9] Kimaryo, L. (2011). Integrating environmental education in primary school education in Tanzania: teachers' perceptions and teaching practices.

[10] Carr, W., \& Kemmis, S. (2003). Becoming critical: education knowledge and action research. Routledge. https://doi.org/10.4324/9780203496626

[11] Diduck, A. (1999). Critical education in resource and environmental management: learning and empowerment for a sustainable future. Journal of Environmental Management, 57(2), 85-97. https://doi.org/10.1006/jema.1999.0289

[12] Rugarcia, A., Felder, R. M., Woods, D. R., \& Stice, J. E. (2000). The future of engineering education I. A vision for a new century. Chemical Engineering Education, 34(1), 16-25.

[13] Lee, J. C. K., \& Williams, M. (2001). Researching environmental education in the school curriculum: An introduction for students and teacher researchers. International Research in Geographical and Environmental Education 10, 218 - 244. https://doi.org/10.1080/ 10382040108667443

[14] Serafin, C. (2019). Information Science in Technical Education Process in Czech Republic. International Journal of Engineering Pedagogy (iJEP), 9(5), 89-102. https://doi.org/10.3991 /ijep.v9i5.11142

[15] MŽP SR. (2015). Rezortná koncepcia environmentálnej výchovy, vzdelávania a osvety do roku 2025. SAŽP. $35 \mathrm{p}$.

[16] SPÚ \& MŠVVŠ SR. Inovovaný štátny vzdelávací program. http://www.statpedu.sk/sk/svp/ inovovany-statny-vzdelavaci-program/

[17] ŠPÚ a). (2017). Environmentálna výchova. Metodické usmernenie k zavádzaniu prierezovej témy do iŠKP. http://www.statpedu.sk/files/sk/aktuality/6-9.2017-metodicke-usmernenie- 
prierezovej-teme-environmentalna-vychova/metodicke-usmernenie-k-prierezovej-temeenvironmeentalna-vychova.pdf

[18] Čajková, G. (2012). Praktická environmentálna výchova I. Osvedčená pedagogická skúsenost' edukačnej praxe. Metodicko-pedagogické centrum, Bratislava. 30 p.

[19] Kelcová, M. \& Kukumbergová, N. (2007). Environmental education in formal education at primary and secondary education. In: Enviromagazín, 12(2), pp. 6-7.

[20] SAŽP. EKOstrediská. https://www.sazp.sk/zivotne-prostredie/environmentalna-vychova-avzdelavanie/

[21] ŠVP a). (2015). Štátny vzdelávací program nižšie stredné vzdelávanie - 2. stupeň základnej školy. Dostupné z: http://www.statpedu.sk/files/articles/dokumenty/inovovany-statnyvzdelavaci-program/svp nsv 62 2015.pdf

[22] ŠVP b). (2015). Manuál na tvorbu školských vzdelávacích programov pre základnú školu. https://www.zsmsorvesele.edu.sk/uploads/fck/file/2016_2017/Manu\%C3\%A11\%20pre\%2 0tvorbu\%20i\%C5\%A0VP.pdf

[23] ŠPÚ b). (2017). Environmentálna výchova. Metodické usmernenie k zavádzaniu prierezovej témy do iŠkVP. Bratislava. http://www.statpedu.sk/files/sk/svp/zavadzanie-isvp-ms-zsgym/gymnazia/prierezove-temy/metodicke-usmernenie-k-prierezovej-temeenvironmentalna-vychova.pdf

[24] ŠPÚ (2015). Technika. Technika - nižšie stredné vzdelávanie. https://www.minedu.sk /data/att/7528.pdf

[25] Činčera, J., Kováčiková, S., Mašková, V., Medal, R., \& Medalová, K. (2012). The Green School: an Impact of Evaluation on Decision-Making about a Program. The New Educational Review, 30(4), 17-29. https://doi.org/10.1080/13504622.2011.557497

[26] Hašková, A.et al. (2015). How to improve professional competences of technical subject teachers. In 2015 9th International Conference on Application of Information and Communication Technologies (AICT) (pp. 536-540). IEEE. https://doi.org/10.1109/ ICAICT.2015.7338618

[27] Novanská, V. (2017). Postoje učitel'ov k využívaniu aktivizujúcich metód v environmentálnej výchove na základných školách. Biológia, Ekológia, Chémia, 21(1)

[28] Hrmo, R., Krištofiaková, L., Miština. J. (2016) Improving the Quality of Technical and Vocational Education in Slovakia for European Labour Market Needs. In: International Journal of Engineering Pedagogy (iJEP). - ISSN 2192-4880. - Vol. 6, no. 2 (2016), pp. 1422. https://doi.org/10.3991/ijep.v6i2.5369

[29] Serafin, C. (2019). Information Science in Technical Education Process in Czech Republic. International Journal of Engineering Pedagogy (iJEP), 9(5), 89-102. https://doi.org/10.3991/ ijep.v9i5.11142

[30] Slovenský štatistický úrad. 2016. Slovenská republika a ciele udržatel'ného rozvoja AGENDY 2030. Bratislava, ISBN 978-80-8121-543-8. $130 \mathrm{~s}$.

[31] Hrmo, R., Krištofiaková, L., Miština, J. (2015). Building a quality system of technical and vocational education in Slovakia towards a European labour market. In: International Confer-ence on Interactive Collaborative Learning (ICL) (pp. 237-243). IEEE. https://doi.org/10.1109/ICL.2015.7318032

[32] Špirála, OZ (2018). Analýza stavu systému environmentálnej výchovy a vzdelávania v Trenčianskom samosprávnom kraji. https://www.minv.sk/swift data/source/rozvoj obcianskej spolocnosti/participacia/vystup y_np parti/PP3$\% 20$ Analyza $\% 20$ stavu $\% 20$ systemu $\% 20$ envronmentalnej $\% 20$ vychovy $\% 20 \mathrm{a} \% 20$ vzdelavani a $\% 20 \mathrm{v} \% 20 \mathrm{TSK} . \mathrm{pdf}$ 
[33] Pantazidou, M., \& Kandris, K. (2020). Examples of Applying Research-Based Learning Principles to the Redesign of an Environmental Geotechnics Course. International Journal of Engineering Pedagogy (iJEP), 10(1), 31-50. https://online-journals.org/index.php/ijep/article/view/11181/6393 https://doi.org/10.3991/ijep.v10i1.11181

\section{Authors}

Ivana Tureková is an Associate professor at the Faculty of Education of the University of Constantine the Philosopher in Nitra, Slovakia. She is an environmental engineer. She guarantees the Bachelor degree in Safety and Health at Work. At present, she deals with technical education aimed at the safety of both students and adults. Email: iturekova@ukf.sk

Jana Bilčíková is an internal $\mathrm{PhD}$ student at the Faculty of Education of the University of Constantine the Philosopher in Nitra, Slovakia. She is a qualified civil engineer, and she taught at secondary schools. She deals with the problematics of education in the field of environmental issues, as a cross-cutting topic, in technical subjects. Email: jana.bilcikova@ukf.sk

Alexander Bilčík is a lecturer at DTI University, Department of Didactics of Specialized Subjects. He is specialized in teaching management systems in technical subjects. Email: bilcik@dti.sk

Iveta Marková is a professor at the University of Žilina, Faculty of Safety Engineering. She is a recognized expert and researcher in the field of fire engineering, environmental protection and explosiveness and flammability of substances, but also in terms of health and safety risks. Email: iveta.markova@fbi.uniza.sk

Article submitted 2020-01-07. Resubmitted 2020-03-10. Final acceptance 2020-03-12. Final version published as submitted by the authors. 